\title{
Ancient genetic divergence in bumblebee catfish of the genus Pseudopimelodus (Pseudopimelodidae: Siluriformes) from northwestern South America
}

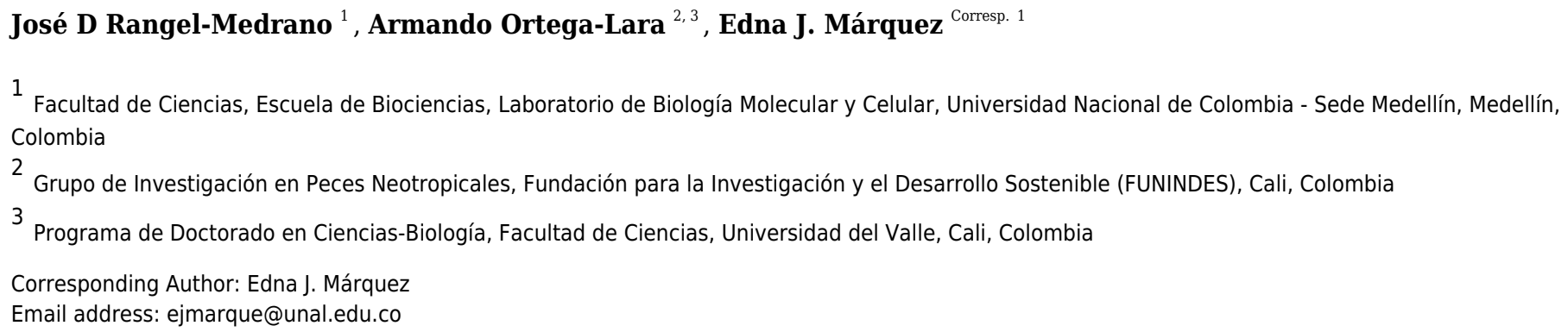

Pseudopimelodus is a Neotropical genus of bumblebee catfish, composed of four valid species occurring in both trans- and cis-Andean rivers of South America. The orogeny of the Andes has led to diversification in the genus Pseudopimelodus in Colombia. This study analyzed partial sequences of mitochondrial cox1 and nuclear rag2 genes to test the hypothesis that the species, nominally recognized as $P$. schultzi and $P$. bufonius in Colombia, correspond to more than two different evolutionary lineages. Results indicate high levels of genetic divergence among individuals of nominal $P$. schultzi and $P$. bufonius, from trans- and cis-Andean basins in Colombia. In addition, five divergent lineages of Pseudopimelodus were confidently delimited by using a single-locus species-discovery approach and confirmed by species tree analyses. Additionally, molecular-clock dating showed that most diversification processes in Pseudopimelodus took place during the Miocene, when Andean tectonic evolution was occurring in northwestern South America. The present study provides, for the first time, phylogeographic insight into this Neotropical genus. 
1 Ancient genetic divergence in bumblebee catfish of the genus

2 Pseudopimelodus (Pseudopimelodidae: Siluriformes) from northwestern

3 South America

4

5 José David Rangel-Medrano ${ }^{1}$, Armando Ortega-Lara ${ }^{2,3}$, Edna J. Márquez ${ }^{1}$

$7 \quad{ }^{1}$ Facultad de Ciencias, Escuela de Biociencias, Laboratorio de Biología Molecular y Celular,

8 Universidad Nacional de Colombia - Sede Medellín, Medellín, Colombia.

$9{ }^{2}$ Grupo de Investigación en Peces Neotropicales, Fundación para la Investigación y el Desarrollo

10 Sostenible (FUNINDES), Cali, Colombia.

11 3Programa de Doctorado en Ciencias-Biología, Facultad de Ciencias, Universidad del Valle,

12 Cali, Colombia.

13

14

15 Correspondence: Edna. J. Márquez, ejmarque@unal.edu.co; ejmarque@gmail.com. 


\section{Abstract}

18 Pseudopimelodus is a Neotropical genus of bumblebee catfish, composed of four valid species

19 occurring in both trans- and cis-Andean rivers of South America. The orogeny of the Andes has

20 led to diversification in the genus Pseudopimelodus in Colombia. This study analyzed partial

21 sequences of mitochondrial coxl and nuclear rag2 genes to test the hypothesis that the species,

22 nominally recognized as $P$. schultzi and P. bufonius in Colombia, correspond to more than two

23 different evolutionary lineages. Results indicate high levels of genetic divergence among

24 individuals of nominal P. schultzi and P. bufonius, from trans- and cis-Andean basins in

25 Colombia. In addition, five divergent lineages of Pseudopimelodus were confidently delimited

26 by using a single-locus species-discovery approach and confirmed by species tree analyses.

27 Additionally, molecular-clock dating showed that most diversification processes in

28 Pseudopimelodus took place during the Miocene, when Andean tectonic evolution was occurring

29 in northwestern South America. The present study provides, for the first time, phylogeographic

30 insight into this Neotropical genus.

31 Keywords: Andean orogeny, Antioqueño Plateau, cis-Andean species, Colombia, Garzón

32 massif, Phylogeography, Pseudopimelodus bufonius, Pseudopimelodus schultzi, trans-Andean

33 species, Vaupes Arch 
35

36

37

38

39

40

41

42

43

44

\section{Introduction}

Pseudopimelodidae is a Neotropical catfish family that includes seven genera and at least 50 valid species, with a distribution ranging from the Atrato River in Colombia to Río de la Plata in Argentina (Fricke, Eschmeyer \& Van der Laan, 2019). Colombia harbors species belonging to six of the seven genera formally described for this family: Batrochoglanis (4 species), Cephalosilurus (1 species) Cruciglanis (1 species), Microglanis (3 species), Pseudopimelodus (2 species), and Rhyacoglanis (1 species) (DoNascimiento et al., 2017). The occurrence of two members of Pseudopimelodus has been recorded in different Colombian rivers, but the distribution of both species remains controversial. For example, a checklist of Colombian freshwater fish circumscribed Pseudopimelodus bufonius (Valenciennes, 1840) to the Caribbean slope rivers (Atrato River, Sinú River, and Catatumbo River), Magdalena-Cauca, Orinoco and Amazon river basins, whereas the endemic species Pseudopimelodus schultzi (Dahl, 1955) was endemic to the Caribbean slope rivers and Magdalena-Cauca River basin (Maldonado-Ocampo et al., 2008). Conversely, a recent revision excluded P. bufonius from the Magdalena-Cauca basin, restricting it to the Caribbean slope rivers and the Orinoco and Amazon river basins (DoNascimiento et al., 2017), while P. schultzi was restricted to the Caribbean slope rivers, including the type locality (Cereté, Córdoba department) of this species of the Sinú River and the Magdalena-Cauca basin.

Furthermore, no phylogeographic studies of Pseudopimelodus have been conducted, leaving a gap in our understanding of the possible effects of geomorphological processes on the diversification of this genus. This gap is important, since phylogeographic analyses may reveal cryptic and deeply divergent lineages that are not reflected in the current taxonomy (Arbogast \& 
58 Kenagy, 2001). Specifically, some geological processes in northwestern South America may

59 have caused vicariant events and subsequent differences in the evolutionary histories of

60 Pseudopimelodus: (1) the uplift of central cordillera during the Late Oligocene-Early Miocene,

61 (2) the isolation of the Atrato-Pacific slope and the Magdalena-Cauca basin with the uplift of the

62 Western Cordillera during the Late Oligocene-Middle Miocene (Duque-Caro, 1990; Colletta et

63 al., 1990; Kellogg \& Vega, 1995), (3) the isolation of the Llanos basin from the Northern

64 Andean Block by the uplift of the eastern Cordillera during the Middle-Late Miocene (Hoorn et

65 al., 1995), and (4) the rise of the Vaupes Arch in the Sub-Andean Foreland region, which divided

66 the present upper Amazonas and upper Orinoco river systems (Hoorn et al., 1995; Lundberg,

67 1998). Thus, we hypothesize that the species nominally recognized as $P$. schultzi and $P$. bufonius

68 in Colombia correspond to more than two separate evolutionary lineages, concordant with basin tectonic evolution in northwestern South America.

To test the hypothesis, we analyzed a partial sequence of the mitochondrially encoded

cytochrome c oxidase I (coxl; COI), which exhibits high rates of molecular evolution, to explore recent divergence events within Pseudopimelodus; we then used the nuclear recombination activating gene 2 ( $\mathrm{rag} 2)$ to explore more ancient phylogenetic relationships among samples of this genus from northwestern South America . Both genes are commonly used in evolutionary studies, due to their adequate variability and ability to reveal phylogenetic relationships and

77 identify freshwater fish species, including members of the superfamily Pimelodoidea (Hubert et al., 2008; Lundberg et al., 2011; Sullivan et al., 2006). Furthermore, we investigated the putative existence of new species and their historical biogeography by using three species-delimitation approaches and dated species tree analysis. This study offers the first insight into the 
81 phylogeographic processes and evolutionary history of pseudopimelodid species from the cis-

82 and trans-Andean region of Colombia.

83

84

Methods

85

Study area and sampling

86

87

This study analyzed a total of 257 Pseudopimelodus muscle tissues from specimens collected in seven hydrographic sub-zones of Colombia (IDEAM, 2015; Table 1, Fig. 1): (1) Magdalena River upper sector, (2) Magdalena River middle sector, (3) Magdalena River and Cauca Riverlower sectors and San Jorge River, (4) Cauca River upper and middle sectors, (5) Caribbean drainage (Atrato River and Sinú River), (6) Amazon River hydrographic zone (Orteguaza River and Vaupés River), and (7) Orinoco River hydrographic zone (Negro River and Meta River).

Muscle tissues of specimens from Magdalena River, Cauca River and Atrato River, preserved in 97\% ethanol, were provided by Integral S.A., through the scientific cooperation agreement CT2013-002443. In addition, muscle tissue from Pseudopimelodus specimens from Sinú River and Orinoco-Amazon hydrographic zones, as well as members of the genera Cruciglanis, Microglanis and Rhyacoglanis, were collected, identified, and provided through the scientific agreements 00466 FUNINDES-INCODER; 0003, 0033, and 00187 FUNINDES-AUNAP; and 037-2014 FUNINDES-HUMEDALES.

Some collection sites were located in sectors with steep slopes in the Magdalena River- upper sector, upstream of the municipality of Honda, which marks the boundary between the upper and the middle Magdalena. Collection sites in the Cauca River upper and middle sectors were located upstream in the Cauca river Canyon, which is the steepest margin of the Antioqueño Plateau in the northern portion of the Central Cordillera (Restrepo-Moreno et al., 2009) and marks the 
104 boundary between the middle and lower sectors of Cauca River. This landform has been

105 considered a geographic barrier for many fish species (Dahl, 1971) and is the focus of the largest

106 hydropower project in Colombia (Hidroituango). Additionally, sampling localities in Magdalena

107 River and Cauca River lower sectors and the San Jorge River correspond to lowlands sites

108 downstream in the Cauca river canyon, including flood plain "ciénagas" that are part of the

109 Momposina depression, one of the most important wetlands in northwestern South America.

110 Finally, collection sites in the cis-Andean hydrographic sub-zones of Orinoco (Meta River and

111 Negro River) and Amazon (Orteguaza River and Vaupés River) are separated by the Vaupes

112 Arch, the major drainage that divide the Llanos region of eastern Colombia (Winemiller \&

113 Willis, 2011).

115 DNA extraction, PCR amplification and sequencing

116 Genomic DNA was extracted using the PureLink ${ }^{\circledR}$ Genomic DNA extraction kit (Invitrogen),

117 following the manufacturer's protocol. For phylogeographic analyses, we amplified a partial

118 region of coxl gene in all 257 specimens, using the universal primer cocktail VF2, FishF2,

119 FishR2 (Ward et al., 2005), and FR1d (Ivanova et al., 2007), as previously published.

120 Furthermore, rag2 gene was amplified from 77 samples, using the primers MHRAG2-F1 and

121 MHRAG2-R1, as reported by Hardman \& Page (2003). For both markers, polymerase chain

122 reactions (PCR) were performed with a total volume of $30 \mu 1$, containing $2.5 \mu 1$ of genomic DNA,

$1233 \mu 110 \mathrm{X}$ buffer, $1.5 \mu 1 \mathrm{MgCl}_{2}(50 \mathrm{Mm}), 0.75 \mu 1 \mathrm{dNTPs}(10 \mathrm{mM}), 0.75 \mu 1$ of the primer cocktail

$124(0.25 \mathrm{pmol} / \mu \mathrm{l}$ each $), 0.15 \mu \mathrm{l}$ of Platinum ${ }^{\mathrm{TM}}$ Taq DNA Polymerase $(5 \mathrm{U} / \mu \mathrm{l})$, and $20.6 \mu 1$ of sterile

125 nuclease-free water (Amresco). The thermal profile for $\operatorname{cox} 1$ consisted of an initial cycle at $95^{\circ} \mathrm{C}$

126 for 3 minutes, 32 cycles of $94^{\circ} \mathrm{C}$ for 3 minutes, 25 seconds at $60^{\circ} \mathrm{C}$, and 30 seconds at $72^{\circ} \mathrm{C}$, and 
127 the final extension was omitted. A similar thermal profile was used to amplify rag2, but with

128 changes in annealing temperature $\left(58^{\circ} \mathrm{C}\right)$ and extension time (45 seconds). PCR products were

129 confirmed by agarose gel electrophoresis and EZ vision staining and sequenced in both forward

130 and reverse directions using an ABI sequencer 3730XL. Sequences were checked and edited

131 using Geneious v10.0.9 (https:/www.geneious.com) software, and multiple alignment to create

132 consensus sequences was performed with the MAFTT v7.308 (Katoh \& Standley, 2013). Both

133 genes were translated into amino acids to confirm absence of stop codons or unexpected

134 frameshift errors using the sequence translation tool Transeq, available in The European

135 Molecular Biology Open Software Suite (EMBOSS

136 https://www.ebi.ac.uk/Tools/st/emboss_transeq/).

137

\section{Genetic diversity and phylogenetic relationships}

139 Calculation of genetic diversity indices, such as number of haplotypes, haplotype (Hd) and

140 nucleotide $(\pi)$ diversity (Nei, 1987), and polymorphic sites, was performed using DNAsp v6

141 (Rozas et al., 2017). Phylogenetic analysis for each gene and concatenated dataset was conducted

142 using Bayesian Inference, with MrBayes (MB) v3.2 (Ronquist et al., 2012), based on the best-fit

143 model estimated in the software IQ-TREE v1.6.12 (Kalyaanamoorthy et al., 2017). Parameters

144 included two independent Markov Chain Monte Carlo (MCMC) iterations for 20 million

145 generations sampled every 1000 generations, discarding the first $25 \%$ sampled generations as

146 burn-in; settings for remaining parameters were left at their default values. Convergence of the

147 MCMC was based on the Potential Scale Reduction Factor (PSRF) approaching 1.0 and the

148 standard deviation of split frequencies approaching 0.0. In addition to sequences obtained in this

149 study, the phylogenetic analysis included previously published rag2 and cox 1 sequences of 
150 species in all other genera of the family Pseudopimelodidae and the pimelodid species

151 Pseudoplatystoma magdaleniatum and Pimelodus yuma as outgroups (Table 1). In addition,

152 spatial relationships of $\operatorname{cox} 1$ haplotypes were explored by constructing a haplotype network

153 based on the Median-Joining algorithm (Bandelt, Forster \& Röhl, 1999), using the software

154 PopART v1.7 (Leigh \& Bryant, 2015).

\section{Species delimitation}

157 Mitochondrial coxl gene sequences were used to implement three single-locus species-discovery 158 (SLSD) methods in R v3.4.163, by using the scripts developed by Machado et al. (2018) and 159 available at https://github.com/legalLab/publications. These methods were implemented to 160 define a priori clusters of putative species (lineages) of Pseudopimelodus as trait values for *BEAST (Heled \& Drummond, 2010) species tree analysis. The three methods implemented corresponded to (1) a divergence threshold optimizing and clustering approach (locMin; Brown et al., 2012), (2) the general mixed Yule coalescent model (GMYC; Pons et al., 2006; Fujisawa \& Barraclough, 2013), and (3) a Bayesian approximation of the GMYC (bGMYC; Reid \& Carstens, 2012). For all analyses, a set of ultrametric trees was generated with BEAST v1.8.4 (Drummond \& Rambaut, 2007) choosing $\mathrm{HKY}+\mathrm{G}$ as the best-fit substitution model, selected by IQ-TREE v1.6.12, setting a relaxed molecular clock model and a Birth-Death Process as a tree prior (Gernhard, 2008). We ran three independent MCMC chains for 20 million sampled every 18,000 generations, discarding the first $10 \%$ of trees as burn-in. Results were combined, and then we sub-sampled a total of 1,000 trees for subsequent analyses. Tracer v1.7 (Rambaut, 2014b)

171 was used to verify convergence and ESS values $(>300)$. 
172 All three analyses were based on point estimates from the maximum clade credibility tree

173 generated using TreeAnnotator v1.8.4 and calculation of confidence intervals from the posterior

174 sample of 1,000 trees. The R packages bGMYC v1.0.2 (Reid \& Carstens, 2012), splits v1.0-19

175 (Fujisawa \& Barraclough, 2013), and ape v4.1 (Paradis, Claude \& Strimmer, 2004) were used in

176 these analyses. A conservative posterior probability of con-specificity at 0.05 were used to

177 summarize the bGMYC posterior samples into putative species.

\section{Species tree and divergence time estimation}

180 We combined sequence information from both mitochondrial cox 1 and nuclear rag2 markers to implement a dated species tree considering the molecular substitution model of each gene using StarBEAST2 v14 (Ogilvie, Bouckaert \& Drummond, 2017) implemented in BEAST2 v2.6.2 (Bouckaert et al. 2014). For both markers we set a strict molecular clock, constant population as population size model and Yule Process for species tree prior. To estimate the time to the most recent common ancestor (TMRCA), and the corresponding credibility intervals (95\% HPD) for the main lineages, two fossil calibrations points were included: one corresponds to the oldest pimelodid fossil from the Paleogene of South America (Gayet \& Otero, 1999) that provide a minimum age of 55.8 million years ago (mya), for the divergence between the families, Pimelodidae and Pseudopimelodidae. This single calibration age constraint was set in the clade including the two pimelodids species used as outgroups, specifying a normal distribution prior, with a standard deviation equal to 1 . Furthermore, an additional fossil calibration corresponding to a cf. Cephalosilurus or Pseudopimelodus from South America middle Miocene (lognormal distribution means 0.1, SD 0.8, offset 11.5, range 15.9-11.5 mya; Lundberg 1998; Lundberg et 
195

196

197

198

199

200

201

202

203

204

205

206

207

208

209

210

211

\section{Results}

213

214

215

216

217

Pseudopimelodus. Analysis was run for 150,000,000 generations sampling every 15,000

generations and discarding the $10 \%$ of the burn-in samples. Convergence was assessed using

Tracer v1.7. The summary of all trees and the annotation of mean ages of all nodes, and the corresponding HPD ranges, was conducted with TreeAnnotator v2.6.0. Finally, the selected tree was visualized using the software FigTree v1.4.3 (Rambaut, 2014a).

We used the MODEL_SELECTION Package v1.5.2 implemented in BEAST2 v2.6.2 to test alternative species tree models for Pseudopimelodus based on the results of SLSD approach. Analyses were performed using the PathSampler icon on the Package Application Launcher, with a path sampling of 10 steps, a chain length of 20 million generations and a burn-in of $10 \%$ with no pre burn-in phase. Remaining parameters were left as default following Leaché et al. (2014). Marginal likelihood estimates (MLE) were obtained for each different model run and Bayes Factor Delimitation methods were used to rank the different species delimitation models. Bayes Factors (BF) were calculated by subtracting the MLE among these models, and then multiplying the difference by two $[\mathrm{BF}=2 \times(\mathrm{MLE} 1-\mathrm{MLE} 0)]$. A positive $\mathrm{BF}$ value indicates support in favor of model 1, while a negative BF value indicates support in favor of model 0 (Leaché \& Bouckaert, 2018).

\section{Sequence analysis and phylogenetic relationships}

Sequence edition yielded a final alignment matrix of a $357 \mathrm{bp}$ and $520 \mathrm{bp}$ fragment for cox land rag2, respectively. No evidence of indels or stop codons was found after translation into amino acids, indicating that the amplified product corresponds to functional cox 1 and rag2 sequences. For the cox 1 dataset, sequence analyses revealed 33 different haplotypes out of 247 sequences 
218 analyzed (GenBank accessions MH553571 - MH553603; MH800618 - MH800835), defined by

21972 polymorphic sites, 52 of which were parsimoniously informative. Values of haplotype and

220 nucleotide diversities for $\operatorname{cox} 1$ dataset were $h=0.761 \pm 0.020$ and $\pi=0.046 \pm 0.001$,

221 respectively. Additionally, sequence analysis of rag2 in the trans-Andean Pseudopimelodus

222 revealed 26 haplotypes of 77 sequences analyzed (GenBank accessions MH595749 -

223 MH595774; MH800567 - MH800617), defined by 22 polymorphic sites, 16 of which were

224 parsimoniously informative. Values of haplotype and nucleotide diversities were $\mathrm{Hd}=0.878 \pm$

2250.024 and $\pi=0.010 \pm 0.000$. According to the Bayesian Information Criterion, the optimal

226 model for cox land rag2 datasets were HKY + G4 and HKY respectively. Collection

227 information, voucher numbers and GenBank accessions for all new sequences obtained in this

228 study are provided in supplementary tables S1 and S2 (see supplemental material).

229 All three SLSD methods consistently suggested five unique molecular delimitations

230 corresponding to lineages 1-5 (Fig. 2). However, we found incongruence among the methods for

231 the delimitation of the valid species P. mangurus (EU179816) and P. charus (EU179815).

232 Pseudopimelodus mangurus was only correctly delimited by GMYC, while P. charus was

233 correctly delimited by locMin and GMYC (Fig. 2). The point estimates were 13 for bGMYC, 15

234 for locMin, and 16 for GMYC. Confidence intervals (95\%) were largest for locMin (12-16

235 species, mean: 14), followed by GMYC (5-19 species, mean: 16), and lowest for bGMYC (4-15

236 species, mean: 11, median: 12, mode: 14).

237 Median joining network (Fig. 3) confirmed these lineages and also showed a deeper genetic

238 divergence between lineage 1 and the remaining Pseudopimelodus lineages, as evidenced by the

239 largest number of mutation steps (19 point mutations). Notably, lineage 1 and lineage 5,

240 represented by a higher number of samples, showed unique haplotypes related to a common 
241 ancestral haplotype distributed in different sampling sites (Fig. 3). Network analysis showed a

242 lineage composed of haplotypes from the Magdalena River middle sector, Magdalena River and

243 Cauca River lower sectors and the San Jorge River (lineage 1); haplotypes from Amazon River

244 hydrographic zone (lineage 2) and Orinoco River hydrographic zone (lineage 3); haplotypes

245 from Atrato River and Sinú River (lineage 4); and haplotypes from the Magdalena River upper

246 sector and, Cauca River upper and middle sectors (lineage 5).

247 The coalescent-based analyses using the MODEL_SELECTION Package ranked the GMYC

248 species delimitation model as the more likely hypothesis (MLE $=-4038.037016)$ instead of the

249 alternatives bGMYC (MLE $=-4042.52818)$ or LocMin (MLE $=-4080.28218)$ models.

250 Moreover, the five evolutionary lineages of Pseudopimelodus were also supported by the dated

251 species tree using the concatenated rag2 and coxl genes (Fig. 4). This analysis in conjunction to

252 all three SLSD models and phylogenetic analysis using MrBayes (Supplementary Figs. 1-3)

253 showed that cox 1 and rag2 recovered the genus Pseudopimelodus as a monophyletic group. In

254 addition, SLSD results and dated species tree support the idea that the genus Rhyacoglanis is a

255 sister clade of Pseudopimelodus plus Cruciglanis.

256 Divergence time estimates (Fig. 4) indicated that lineage 1 diverged from all remaining members 257 of Pseudopimelodus during Middle Miocene (16.21 mya 95\% HDP 11.91-20.79). Similarly, a

258 Middle Miocene split was detected between lineage 2 and the clade comprising lineages 3, 4 and

2595 (12.37 mya HPD 8.98-16.23), while a Late Miocene divergence was detected between lineage

2603 and the clade formed by lineages 4 and 5 (9.93 mya HPD 6.54-13.20), and between lineages 4

261 and 5 (5.28 mya HPD 1.61-8.20). 


\section{Discussion}

264 This study tested the hypothesis that the species nominally recognized as $P$. schultzi and $P$.

265 bufonius in Colombia correspond to more than two different evolutionary lineages, the

266 divergence times of which agree with Andean tectonic evolution in northwestern South America.

267 Our expectation was that geological events induced vicariance in Pseudopimelodus from

268 northwestern South America. Despite the limitations of using short fragments, the use of nuclear

269 and mitochondrial molecular markers, with different mutational rates, allowed us to infer

270 ancient, as well as more recent, genetic divergence in this group of bumblebee catfish. In this

271 study, we did not cover the complete geographical range where nominal P. bufonius occurs in

272 Colombia; instead, we analyzed only a small number of individuals from the cis-Andean portion.

273 Thus, the detected haplotypes may not represent all genetic lineages present in this geologically

274 complex region.

275 Mitochondrial cox 1 and nuclear rag2 analyses supported our hypothesis of divergent lineages of

276 Pseudopimelodus inhabiting trans and cis-Andean rivers in Colombia. Indeed, the molecular

277 evidence gathered in this study supports the non-monophyly of $P$. bufonius and $P$. schultzi, based

278 on the strong genetic divergence among specimens identified as P. schultzi representing

279 populations from Magdalena, Cauca, Atrato, and Sinú rivers, and among nominal P. bufonius

280 from the Amazon and Orinoco rivers. Specifically, trans-Andean P. schultzi includes three

281 divergent lineages: (1) Magdalena River lower and middle sectors, Cauca River lower sector and

282 San Jorge River, (2) Magdalena River upper sector, Cauca River upper and middle sectors, and

283 (3) Sinú and Atrato rivers. Moreover, P. bufonius populations from the cis-Andean region of

284 Colombia include two divergent lineages: (1) Orinoco River hydrographic zone and (2) Amazon

285 River hydrographic zone. 
286 We found perfect congruence among all SLSD methods in delimiting the above-mentioned

287 lineages, and species tree analysis supported these results, indicating that at least four new

288 candidate species, previously synonymized with P. schultzi and P. bufonius, occur in Colombia.

289 This outcome suggests that a robust taxonomic revision of Pseudopimelodus, and especially $P$.

290 bufonius, is needed; future studies should include samples from the type locality (Cayenne,

291 French Guiana; Boeseman, 1972), since considering our results, it is reasonable to think that the

292 species present in the Colombian cis- and trans-Andean rivers may not correspond to P. bufonius

293 sensu stricto.

294 Furthermore, inter-generic relationships detected in this study, especially those observed with 295 coxl results using BEAST and SLSD methods that showed that Pseudopimelodus is sister to 296 Cruciglanis, and this clade is sister to Rhyacoglanis, support recent phylogenetic studies on 297 morphological characters and data of gross morphology from the brain of Pseudopimelodidae 298 (Shibatta \& Vari, 2017; Abrahão et al., 2018). However, further research, using more markers 299 and a larger sample size, is required to completely clarify the phylogenetic relationships of the 300 family Pseudopimelodidae and its place in a biogeographic framework of Neotropical 301 diversification (Machado et al., 2018).

302 Given the geographic distribution of each identified lineage, and the general branching of the 303 tree topology, the results agree with the geological history of the Andean mountains in 304 Northwestern South America and support previously proposed models of ichthyofauna division, 305 based on several species-level phylogenies (Albert, Lovejoy, \& Crampton, 2006). Patterns of 306 divergence, in concordance with the geological evolution of Northwestern South America found 307 in this study, have also been reported in other fishes (Hernández et al., 2015; Machado, Galetti \& 308 Carnaval, 2018; Rincón-Sandoval, Betancur \& Maldonado-Ocampo, 2019) and other taxa such 
309 as mammals (Coimbra et al., 2017) and insects (Salgado-Roa et al., 2018; Bartoleti et al., 2018).

310 In addition, our results support a north to south uplift of the Colombian Andes (Florez, 2003), as

311 diversification of Pseudopimelodus occurred in a sequential manner from older lower altitude

312 diversification events to younger higher altitude diversification events, as was also reported in

313 Neotropical plant species in Colombia (Richardson et al., 2018).

314 The Middle Miocene divergence of lineage 1, which exhibited the deepest divergence of the

315 detected lineages, strongly agrees with the onset of the Eu-Andina phase of the Northern Andes

316 (18 mya to present), previously reported by Van der Hammen (1960). During this phase, the

317 Antioqueño Plateau (the largest high-elevation erosional surface in the Northern Andes) attained

318 its actual elevation in the central Cordillera, from the raising of the erosion surface from close to

319 sea level to $3600 \mathrm{~m}$ a.s.1. (Restrepo-Moreno et al., 2009). This result is concordant with the fact

320 that lineage 1 is predominantly present down-stream of the Cauca River Canyon, which is the

321 steepest margin of the Antioqueño Plateau (Restrepo-Moreno et al., 2009).

322 Furthermore, the divergence between lineage 2 and the clade containing lineages 3, 4 and 5 was 323 estimated to be at 12.37 mya (HPD 8.98-16.23). This estimated date is consistent with the first

324 development of the Amazon River during the late-middle Miocene, when the paleo-Amazon

325 River was still partly connected to the paleo-Orinoco, through a fluvio-lacustrine system (Hoorn

326 et al., 1993; Hoorn et al., 1995). Then, the "paleo-Amazon-Orinoco" split into two different

327 Atlantic-draining basins at approximately 8-10 mya, as result of the elevation of the Vaupes

328 Arch in the region comprising the southern area of the Colombian Llanos (Cooper et al., 1995;

329 Hoorn et al., 1995; Lundberg, 1998). Previous studies have also yielded evidence of allopatric

330 sister lineages of freshwater fish, isolated by this Amazonas-Orinoco vicariance event

331 (Sivasundar et al., 2001; Winemiller et al., 2008; Machado et al., 2018). 
332 The Late Miocene divergence (9.93 mya HPD 6.54-13.20) observed between lineage 3 and the

333 clade containing lineages 4 and 5, agrees with the uplift of Eastern Cordillera (10 mya; Gregory-

334 Wodzicki, 2000) that permanently divided the former foreland basin into the Magdalena and

335 Llanos basins (Hoorn et al, 1995). However, the Eastern Cordillera was not a substantial

336 orographic barrier, as there must have been a low-elevation fluvial corridor between the

337 Magdalena Valley and the eastern Orinoco plains connecting these two geographic provinces

338 (Richardson et al., 2018). This may explain the closer phylogenetic relationships detected

339 between lineage 3 (haplotypes from Orinoco hydrographic zone) and the trans-Andean lineages

3404 and 5. This fluvial corridor may correspond to the area of the Garzón Massif (between latitudes

$\left.3411^{\circ}-4^{\circ} \mathrm{N}\right)$, located in the southeastern flank of the Eastern Cordillera in the Colombian Andes

342 (Altenberger et al., 2012), which has suffered a more recent and rapid exhumation process

343 (Anderson et al., 2016). In fact, Anderson et al. (2016) states that an important barrier to

344 dispersal was not fully established in the Eastern Cordillera until the latest Miocene-Pliocene (ca.

345 6-3 mya) phase of the rapid exhumation of the Garzón basement.

346 Moreover, the splitting of lineage 4 from lineage 5 occurred during the late Miocene (5.28 mya

347 HPD 1.61-8.20), concordant with the uplift of the Western Cordillera that caused the isolation of

348 the trans-Andean Atrato-Pacific slope from the Magdalena basin during Late Miocene to

349 Pliocene (Kellogg \& Vega, 1995). In addition, the close relationship of samples from the Atrato

350 and Sinú rivers (lineage 4) supports the previous hypothesis that a historical connection resulting

351 from headwater stream capture existed between the adjacent Atrato and Sinú basins; that was

352 posteriorly isolated by the uplift of Western Cordillera during the Miocene (Rincon-Sandoval,

353 Betancur \& Maldonado-Ocampo, 2019). 
354 Altogether, the results obtained in this study provide a better understanding of the

355 phylogeographic processes that govern the current distribution and diversification of freshwater

356 ichthyofauna in northwestern South America. Moreover, as shown by SLSD and species tree

357 results, the taxonomic diversity within Pseudopimelodus is currently underestimated, which can

358 affect the estimation of species richness, jeopardize the understanding of ecological patterns, and

359 may be harmful to species at a high risk of extinction (Vogel Ely et al., 2017). In light of these

360 results, ongoing studies of morphological analyses, including osteology and external

361 morphology, we are describing two new Pseudopimelodus species from the Magdalena-Cauca

362 River Basin, corresponding to lineages 1 and 5 described herein (Restrepo-Gómez et al.,

363 submitted). Finally, and independently of taxonomic implications, genetic divergence of

364 Pseudopimelodus lineages must be considered in current conservation and management policies 365 of Colombian bumblebee catfish fisheries.

\section{Conclusions}

368 This study provides strong mtDNA evidence that the genus Pseudopimelodus in Colombia comprises at least five different, clearly delimited, evolutionary lineages. The lineages exhibit

370 phylogenetic histories that agree with the geological history of northwestern South America. We

371 recommend that future genetic studies include more genetic markers and a greater number of

372 samples, from additional localities, to examine more thoroughly and provide a deeper

373 understanding of the phylogeographic patterns of this genus in South America. These results

374 contribute to the phylogeographic knowledge of Pseudopimelodids inhabiting cis and trans-

375 Andean river systems in Colombia and provide an important benchmark for future phylogenetic

376 studies in this diverse and widespread Neotropical catfish family. 


\section{Acknowledgments}

379 This paper is dedicated to the memory of our admirable colleague and friend Dr. Javier

380 Alejandro Maldonado Ocampo who recently passed away in a tragic accident in the Vaupés

381 River. Authors would also like to acknowledge the valuable comments of Carolina de Barros

382 Machado da Silva and the anonymous reviewers that improved the manuscript.

\section{References}

385

386

387

388

389

390

391

392

393

394

395

396

397

Abrahão VP, Pupo FM, Shibatta OA. 2018. Comparative brain gross morphology of the Neotropical catfish family Pseudopimelodidae (Osteichthyes, Ostariophysi, Siluriformes), with phylogenetic implications. Zoological Journal of the Linnean Society XX 1-23. https://doi.org/10.1093/zoolinnean/zly011/4959345.

Albert JS, Lovejoy NR, Crampton WGR. 2006. Miocene tectonism and the separation of cis- and trans-Andean river basins: Evidence from Neotropical fishes. Journal of South American Earth Sciences 21(1-2):14-27 https://doi.org/10.1016/j.jsames.2005.07.010.

Altenberger U, Mejía-Jimenez DM, Günter C, Sierra-Rodriguez GI, Scheffler F, Oberhänsli R. 2012. The Garzón Massif, Colombia-a new ultrahigh-temperature metamorphic complex in the Early Neoproterozoic of northern South America. Mineralogy and Petrology 105: 171-185 https://doi.org/10.1007/s00710-012-0202-1.

Anderson VJ, Horton BK, Saylor JE, Mora A, Tesón E, Breecker DO, Ketcham RA. 2016. Andean topographic growth and basement uplift in southern Colombia: Implications for 
the evolution of the Magdalena, Orinoco, and Amazon river systems. Geosphere 12(4): 1235-1256 https://doi.org/10.1130/GES01294.1.

Arbogast BSBS, Kenagy GJJ. 2001. Comparative phylogeography as an integrative approach to historical biogeography. Journal of Biogeography 28:819-825 https://doi: 10.1046/j.1365-2699.2001.00594.x.

Bartoleti, LF Peres de M, Fontes EA, von Hertwig F, Fontes M, da Silva MJ, Solferini VN. 2018. Phylogeography of the widespread spider Nephila clavipes (Araneae: Araneidae) in South America indicates geologically and climatically driven lineage diversification. Journal of Biogeography 45:1246-1260 https://doi.org/10.1111/jbi.13217.

Bandelt H, Forster P, Röhl A. 1999. Median-joining networks for inferring intraspecific phylogenies. Molecular Biology and Evolution 16(1):37-48.

Boeseman M. 1972. Notes on South American catfishes, including remarks on Valenciennes and Bleeker types in the Leiden Museum. Zoologische Mededelingen (Leiden) 47(23): 293320 Pls. 1-2.

Bouckaert R, Heled J, Kühnert D, Vaughan T, Wu CH, Xie D, Suchard MA, Rambaut A, Drummond AJ. 2014. BEAST 2: A Software Platform for Bayesian Evolutionary Analysis. PLoS Computational Biology 10(4): 1-6. https://doi.org/10.1371/journal.pcbi.1003537.

Brown SDJ, Collins RA, Boyer S, Lefort M, Malumbres-olarte J, Vink CO, Cruickshank RH. 2012. SPIDER: An R package for the analysis of species identity and evolution, with particular reference to DNA barcoding. Molecular Ecology Resources 12:562-565 https://doi.org/10.1111/j.1755-0998.2011.03108.x. 
420 Coimbra RTF, Miranda FR, Lara CC, Schetino MAA, dos Santos FR. 2017. Phylogeographic

421

422

423

424

425

426

427

428

429

430

431

432

433

434

435

436

437

438

439

440 history of South American populations of the silky anteater cyclopes didactylus (Pilosa:

Cyclopedidae). Genetics and Molecular Biology 40(1):40-49

https://doi.org/10.1590/1678-4685-GMB-2016-0040.

Colletta B, Hebrard F, Letouzey J, Werner P, Rudkiewicz JL. 1990. Tectonic and crustal structure of the Eastern Cordillera (Colombia) from a balanced cross-section. In: Letouzey, J. (Ed.), Petroleum and Tectonics in Mobile Belts. Editions Technip, Paris, France, pp. 80-100.

Cooper MA, Addison FT, Alvarez R, Coral M, Graham RH, Hayward AB, Howe S, Martinez J, Naar J, Penas R, Pulham AJ, Taborda A. 1995. Basin development and tectonic history of the Ilanos basin, Eastern Cordillera, and Middle Magdalena valley, Colombia. Bulletin of the American Association of Petroleum Geologists 79:1421-1443.

Dalh G. 1971. Género Prochilodus. In Peces del Norte de Colombia. (Dalh G ed): 109-111. Bogotá, DC: INDERENA.

De Carvalho DC, Oliveira DAA, Pompeu PS, Leal CG, Oliveira C, Hanner R. 2011. Deep barcode divergence in Brazilian freshwater fishes: The case of the São Francisco River basin. Mitochondrial DNA 22 sup1:80-86 DOI 10.3109/19401736.2011.588214.

DoNascimiento C, Herrera-Collazos EE, Herrera GA, Ortega-Lara A, Villa-Navarro FA, Usma Oviedo JS, Maldonado-Ocampo JA. 2017. Checklist of the freshwater fishes of Colombia: a Darwin Core alternative to the updating problem. ZooKeys 708:25-138 https://doi.org/10.3897/zookeys.708.13897.

Peer) reviewing PDF | (2018:07:29424:2:1:NEW 21 Mar 2020) 
441 Duque-Caro H. 1990. Neogene stratigraphy, paleoceanography and paleobiogeography in

442

443

444

445

446

447

448

449

450

451

452

453

454

455

456

457

458

459

460

northwest South America and the evolution of the Panama Seaway. Palaeoclimatology, Palaeogeography, Palaeoecology 77:203-234.

Drummond AJ, Rambaut A. 2007. BEAST: Bayesian evolutionary analysis by sampling trees. BMC Evolutionary Biology 7(1):214 https://doi.org/10.1186/1471-2148-7-214.

Florez A. 2003. Colombia: evolución de sus relieves y modelados. Universidad Nacional de Colombia. 238 p.

Fricke R, Eschmeyer WN, Van der Laan R. (eds). 2019. Eschmeyer's Catalog of Fishes: Geneta, Species, References. (http://researcharchive.calacademy.org/research/ichthyology/catalog/fishcatmain.asp). Electronic version accessed 02-10-2019.

Fujisawa T, Barraclough T. 2013. Delimiting species using single-locus data and the generalized mixed Yule coalescent approach: A revised method and evaluation on simulated data sets. Systematic Biology 62:707-724 https://doi.org/10.1093/sys-bio/syt033.

Gernhard T. 2008. The conditioned reconstructed process. Journal of Theoretical Biology 253(4):769-778 https://doi.org/10.1016/j.jtbi.2008.04.005.

Gayet M, Otero O. 1999. Analysis of the palaeodiversification of the Siluriformes (Osteichthyes, Teleostei, Ostariophysi). Geobios 32:235-246.

Gregory-Wodzicki KM. 2000. Uplift history of the Central and Northern Andes: A review. GSA Bulletin 112:1091-1105. 
461 Hardman M, Page LM. 2003. Phylogenetic relationships among bullhead catfishes of the genus

462

463

464

465

466

467

468

469

470

471

472

473

474

475

476

477

478

479

480

481

482

Ameiurus (Siluriformes: Ictaluridae). Copeia 1:20-33 https://doi.org/10.1643/00458511(2003)003[0020:prabco]2.0.co;2

Hardman M, Lundberg JG. 2006. Molecular phylogeny and a chronology of diversification for "phractocephaline" catfishes (Siluriformes: Pimelodidae) based on mitochondrial DNA and nuclear recombination activating gene 2 sequences. Molecular Phylogenetics and Evolution 40(2):410-418 https://doi.org/10.1016/j.ympev.2006.03.011.

Heled J, Drummond AJ. 2010. Bayesian Inference of Species Trees from Multilocus Data. Molecular Biology and Evolution 27(3):570-580 https://doi.org/10.1093/molbev/msp274.

Hernández CL, Ortega-Lara A, Sánchez-Garcés GC, Alford, M. 2015. Genetic and Morphometric Evidence for the Recognition of Several Recently Synonymized Species of Trans-Andean Rhamdia (Pisces: Siluriformes: Heptapteridae). Copeia 103(3):563-579 https://doi.org/10.1643/CI-14-145.

Hoorn C. 1993. Marine incursions and the influence of Andean tectonics on the Miocene depositional history of northwestern Amazonia: Results of a palynostratigraphic study. Palaeoclimatology, Palaeogeography, Palaeoecology 105: 267-309 https: //doi.org/10.1016/0031-0182(93)90087-Y.

Hoorn C, Guerrero J, Sarmiento GA, Lorente MA. 1995. Andean Tectonics as a Cause for Changing Drainage Patterns in Miocene Northern South-America. Geology 23:237-240 https://doi.org/10.1130/0091-7613.

Hubert N, Hanner R, Holm E, Mandrak, NE, Taylor E, Burridge M, Watkinson D, Dumont P, Curry A, Bentzen P, Zhang J, April J, Bernatchez L. 2008. Identifying Canadian 
483

484

485

486

487

488

489

490

491

492

493

494

495

496

497

498

499

500

501

502

503

freshwater fishes through DNA barcodes. PLoS ONE 3(6): e2490

https://doi.org/10.1371/journal.pone.0002490.

IDEAM. 2015. Estudio Nacional del Agua. Bogotá, 496 pp.

Ivanova NV, Zemlak TS, Hanner RH, Hebert PDN. 2007. Universal primer cocktails for fish DNA barcoding. Molecular Ecology Notes 7(4):544-548 https://doi.org/10.1111/j.14718286.2007.01748.x.

Kalyaanamoorthy S, Minh BQ, Wong TKF, Von Haeseler A, Jermiin LS. 2017. ModelFinder: Fast model selection for accurate phylogenetic estimates. Nature Methods 14:587-589. https://doi.org/10.1038/nmeth.4285.

Katoh K, Standley, DM. 2013. MAFFT multiple sequence alignment software version 7: Improvements in performance and usability. Molecular Biology and Evolution 30(4): 772-780 https://doi.org/10.1093/molbev/mst010.

Kellogg JN, Vega V. 1995. Vega Tectonic development of Panama, Costa Rica, and the Colombian Andes: Constraints from Global Positioning System Geodetic Studies and Gravity. Geological Society of America Special Paper 295:75-90.

Leaché AD, Fujita MK, Minin VN, Bouckaert RR. 2014. Species delimitation using genomewide SNP Data. Systematic Biology 63(4): 534-542.

Leaché AD, Bouckaert RR. 2018. Species Trees and Species Delimitation with SNAPP: A Tutorial and Worked Example. Available at http://evomicsorg.wpengine.netdnacdn.com/wp-content/uploads/2018/01/BFD-tutorial-1.pdf (accessed 2 March 2020)https://doi.org/10.1093/sysbio/syu018. 
504 Leigh JW, Bryant D. 2015. PopART: Full-feature software for haplotype network construction.

505

506

507

508

509

510

511

512

513

514

515

516

517

518

519

520

521

522

523

524

Methods in Ecology and Evolution 6(9):1110-1116 https://doi.org/10.1111/2041210X.12410.

Lundberg JG. 1998. The stage for Neotropical fish diversification: A history of tropical South American rivers. In LR Malabarba, RP Vari, ZMS Lucena, CAS Lucena (Eds.), Phylogeny and classification of Neotropical fishes. Porto Alegre: EDIPUCRS.

Lundberg JG, Sabaj Pérez MH, Dahdul W, Aguilera O. 2010. The Amazonian Neogene Fish Fauna. Amazonia: Landscape and Species Evolution: A look into the past. 281-301 https://10.1002/9781444306408.ch17.

Lundberg JG, Sullivan JP, Hardman M. 2011. Phylogenetics of the South American Catfish Family Pimelodidae (Teleostei: Siluriformes) using Nuclear and Mitochondrial Gene Sequences. Proceedings of the Academy of Natural Sciences of Philadelphia 161(1): 153-189 https://doi.org/10.1635/053.161.0110.

Machado VN, Collins RA, Ota RP, Andrade MC, Farias IP, Hrbek T. 2018. One thousand DNA barcodes of piranhas and pacus reveal geographic structure and unrecognized diversity in the Amazon. Scientific Reports 8:1-12 https://doi.org/10.1038/s41598-018-26550-x.

Machado CB, Galetti PM, Carnaval AC. 2018. Bayesian analyses detect a history of both vicariance and geodispersal in Neotropical freshwater fishes. Journal of Biogeography 45(6):1313-1325 https://doi.org/10.1111/jbi.13207.

Maldonado-Ocampo J, Vari R, Usma J. 2008. Checklist of the freshwater fishes of Colombia. Biota Colombiana 9 (2):143-237. 
525 Nei M. 1987. Molecular Evolutionary Genetics. Columbia University Press. New York.

526 Ogilvie HA, Bouckaert RR, Drummond AJ. 2017. StarBEAST2 brings faster species tree

527 inference and accurate estimates of substitution rates. Molecular Biology and Evolution

528 34(8): 2101-2114. https://doi.org/10.1093/molbev/msx126.

529 Paradis E, Claude J, Strimmer K. 2004. APE: analyses of phylogenetics and evolution in R 530 language. Bioinformatics 20:289-290 https://doi.org/10.1093/bioinformatics/btg412.

531 Pons J, Barraclough TG, Gomez-zurita J, Cardoso A. 2006. Sequence-Based Species

532

533 Delimitation for the DNA Taxonomy of Undescribed Insects. Systematic Biology 55(4):595-609 https://doi.org/10.1080/10635150600852011.

Rambaut A. 2014a. FigTree Version 1.4.3.

535

Rambaut A. 2014b. Tracer v1.7 Available from <http://beast.bio.ed.ac.uk/Tracer $>$.

536 Restrepo-Moreno SA, Foster DA, Stockli DF, Parra-Sánchez, LN. 2009. Long-term erosion and 537 exhumation of the "Altiplano Antioqueño", Northern Andes (Colombia) from apatite (UTh)/He thermochronology. Earth and Planetary Science Letters 278:1-12

Reid NM, Carstens BC. 2012. Phylogenetic estimation error can decrease the accuracy of species delimitation: a Bayesian implementation of the general mixed Yule-coalescent model. dated molecular phylogenies to help reconstruct geological, climatic, and biological 
546

547

548

549

550

551

552

553

554

555

556

557

558

559

560

561

562

563

564

565

history: Examples from Colombia. Geological Journal 53(6): 2935-2943

https://doi.org/10.1002/gj.3133.

Rincón-Sandoval M, Betancur R, Maldonado-Ocampo J. 2019. Comparative Phylogeography of Trans-Andean Freshwater Fishes Based on Genome-Wide Nuclear and Mitochondrial Markers. Molecular ecology 28(5): 1096-1115 https://doi.org/10.5061/dryad.81pq863.

Ronquist F, Teslenko M, Van Der Mark P, Ayres DL, Darling A, Höhna S, Huelsenbeck JP. 2012. Mrbayes 3.2: Efficient Bayesian phylogenetic inference and model choice across a large model space. Systematic Biology 61(3):539-542 https://doi.org/10.1093/sysbio/sys029.

Rozas J, Ferrer-Mata A, Sánchez-DelBarrio JC, Guirao-Rico S, Librado P, Ramos-Onsins SE, Sánchez-Gracia A. 2017. DnaSP 6: DNA Sequence Polymorphism Analysis of Large Datasets. Molecular Biology and Evolution 34:3299-3302 https://doi.org/10.1093/molbev/msx248.

Salgado-Roa FC, Pardo-Diaz C, Lasso E, Arias CF, Solferini VN, Salazar C. 2018. Gene flow and Andean uplift shape the diversification of Gasteracantha cancriformis (Araneae: Araneidae) in Northern South America. Ecology and Evolution 8:7131-7142 https://doi.org/10.1002/ece3.4237.

Shibatta OA, Vari RP. 2017. A new genus of Neotropical rheophilic catfishes, with four new species (Teleostei: Siluriformes: Pseudopimelodidae). Neotropical Ichthyology 15(2):1-30 https://doi.org/10.1590/1982-0224-20160132. 
566 Sivasundar A, Bermingham E, Orti G. 2001. Population structure and biogeography of migratory

567

568

569

570

571

572

573

574

575

576

577

578

579

580

581

582

583

584

585

586

587

freshwater fishes (Prochilodus: Characiformes) in major South American rivers. Molecular Ecology 10:407-417 https://doi.org/10.1046/j.1365-294x.2001.01194.x.

Sullivan JP, Lundberg JG, Hardman M. 2006. A phylogenetic analysis of the major groups of catfishes (Teleostei: Siluriformes) using rag1 and rag2 nuclear gene sequences. Molecular Phylogenetics and Evolution 41(3):636-662 https://doi.org/10.1016/j.ympev.2006.05.044.

Sullivan JP, Muriel-Cunha J, Lundberg JG. 2013. Phylogenetic Relationships and Molecular Dating of the Major Groups of Catfishes of the Neotropical Superfamily Pimelodoidea (Teleostei, Siluriformes). Proceedings of the Academy of Natural Sciences of Philadelphia 162(1):89-110 https://doi.org/10.1635/053.162.0106.

Van der Hammen, T. 1960. Estratigrafía del Terciario y Maestrichtiano continentales y tectogénesis de los Andes Colombianos, Informe No. 1279. Servicio Geológico Nacional Bogotá. 128 pp.

Vogel Ely C, de Loreto Bordignon SA, Trevisan R, Boldrini II. 2017. Implications of poor taxonomy in conservation. Journal for Nature Conservation 36:10-13. https://doi.org/10.1016/J.JNC.2017.01.003.

Ward RD, Zemlak TS, Innes BH, Last PR, Hebert PDN. 2005. DNA barcoding Australia's fish species. Philosophical Transactions of the Royal Society of London. Series B, Biological Sciences 360:1847- 1857 https://doi.org/10.1098/rstb.2005.1716.

Winemiller KO, López-Fernández H, Taphorn DC, Nico LG, Duque AB. 2008. Fish assemblages of the Casiquiare River, a corridor and zoogeographical filter for dispersal 
588 between the Orinoco and Amazon basins. Journal of Biogeography 35(9):1551-1563

$589 \quad$ https://doi.org/10.1111/j.1365-2699.2008.01917.x.

590 Winemiller KO, Willis SC. 2011. The Vaupes Arch and Casiquiare Canal: Barriers and

591 Passages. In: Albert JS. and Reis RE. Eds. Historical Biogeography of Neotropical

$592 \quad$ Freshwater Fishes 225-242p

$593 \quad$ https://doi.org/10.1525/california/9780520268685.003.0014.

594 Yu G, Smith DK, Zhu H, Guan Y, Lam TTY. 2016. GGTREE: An R package for visualization 595 and annotation of phylogenetic trees with their covariates and other associated data.

596 Methods in Ecology and Evolution 8:28-36 https://doi.org/10.1111/2041-210X.12628. 


\section{Table $\mathbf{1}$ (on next page)}

List of Pseudopimelodidae sequences generated in this study and GenBank sequences used for analysis.

C: Colombia, V: Venezuela, B: Brazil, P: Perú, ${ }^{b}$ Basin, ' River, HZ1: Magdalena River-upper sector, HZ2: Magdalena River-middle sector, HZ3: Magdalena River and Cauca River- lower sectors and San Jorge River, HZ4: Cauca River-upper and middle sectors, HZ5: Caribbean drainage - Atrato River and Sinú River, HZ6: Amazon River basin, HZ7: Orinoco River basin. References: 1: This study, 2: Sullivan et al (2013), 3: C Oliveira, 2018, pers. comm., 4: Sullivan et al (2006), 5: Hardman \& Lundberg (2006), 6: de Carvalho et al., (2011). GPS coordinates for each haplotype are provided in supplementary information. 


\begin{tabular}{|c|c|c|c|c|c|}
\hline \multirow{2}{*}{ Species } & \multirow{2}{*}{ Country } & \multirow{2}{*}{ Origin } & \multicolumn{2}{|c|}{ GenBank accession (Haplotype) } & \multirow{2}{*}{ Reference } \\
\hline & & & rag2 & $\operatorname{cox} 1$ & \\
\hline Pseudopimelodus schultzi & $\mathrm{C}$ & HZ1-Magdalena $^{\mathrm{r}}$ & MH595766 (H18) & MH553588 (H18) & 1 \\
\hline Pseudopimelodus schultzi & $\mathrm{C}$ & HZ2-Magdalena ${ }^{r}$ & MH595752 (H4) & MH553578 (H8) & 1 \\
\hline Pseudopimelodus schultzi & $\mathrm{C}$ & HZ3-Magdalena ${ }^{\mathrm{r}}$ & MH595751 (H3) & MH553580 (H10) & 1 \\
\hline Pseudopimelodus schultzi & $\mathrm{C}$ & HZ3-Cauca ${ }^{\mathrm{r}}$ & MH595749 -50 (H1-2) & $\begin{array}{l}\text { MH553573-77 (H3-7), MH553579 (H9), MH553581- } \\
82 \text { (H11-H12) }\end{array}$ & 1 \\
\hline Pseudopimelodus schultzi & $\mathrm{C}$ & HZ3-San Jorger ${ }^{r}$ & MH595768 (H20) & MH553571-72 (H1-2) & 1 \\
\hline Pseudopimelodus schultzi & $\mathrm{C}$ & HZ4-Cauca ${ }^{\mathrm{r}}$ & $\begin{array}{l}\text { MH595753 (H5), MH595758 (H10), MH595764 } \\
\text { (H16), MH595767 (H19) }\end{array}$ & MH553591 (H21), MH553593-94 (H23-24) & 1 \\
\hline Pseudopimelodus schultzi & $\mathrm{C}$ & HZ4-Cauca ${ }^{\mathrm{r}}$ & $\begin{array}{l}\text { MH595756 (H8), MH595759-60 (H12-13), } \\
\text { MH595763 (H15), MH595765 (H17) }\end{array}$ & $\begin{array}{l}\text { MH553583-86 (H13-16), MH553587 (H17), } \\
\text { MH553589-90 (H19-20) }\end{array}$ & 1 \\
\hline Pseudopimelodus schultzi & $\mathrm{C}$ & HZ5-Atrator & MH595757 (H9), MH595762 (H14) & MH553592 (H22) & 1 \\
\hline Pseudopimelodus schultzi & $\mathrm{C}$ & HZ5-Sinúr & MH595754-55 (H6-7), MH595759 (H11) & MH553595-96 (H25-26) & 1 \\
\hline Pseudopimelodus bufonius & $\mathrm{C}$ & HZ6-Orinoco ${ }^{\mathrm{b}}$ & MH595769-71 (H21-23), MH595773 (H25) & MH553597 (H27), MH553600 (H30) & 1 \\
\hline Pseudopimelodus bufonius & $\mathrm{C}$ & HZ7-Amazon ${ }^{\mathrm{b}}$ & MH595772 (H24), MH595774 (H26) & MH553598-99 (H28-29), MH553601-03 (H31-33) & 1 \\
\hline Pseudopimelodus bufonius & $\mathrm{V}$ & Maracaibo $^{\mathrm{b}}$ & DQ492359 & -- & 2 \\
\hline Pseudopimelodus mangurus & $\mathrm{B}$ & Paranapanema ${ }^{\mathrm{r}}$ & -- & EU179816 & 3 \\
\hline Pseudopimelodus mangurus & $\mathrm{B}$ & Uruguay $^{\mathrm{r}}$ & DQ492360 & --- & 2 \\
\hline Batrochoglanis raninus & $\mathrm{B}$ & Aquarium & -- & EU179809 & 3 \\
\hline Batrochoglanis raninus & $\mathrm{P}$ & Nanayb & DQ492361 & -- & 4 \\
\hline Cephalosilurus apurensis & $\mathrm{V}$ & Orinoco $^{b}$ & DQ486780 & --- & 5 \\
\hline Cephalosilurus apurensis & $\mathrm{V}$ & Orinoco $^{\mathrm{b}}$ & --- & EU179818 & 3 \\
\hline Cruciglanis pacifici & $\mathrm{C}$ & Anchicayár $^{r}$ & MH553598 (AOL94) & MH553607 (AOL94), MH553608 (AOL23) & 1 \\
\hline Cruciglanis sp. & $\mathrm{C}$ & Mira $^{\mathrm{r}}$ & MH553597 (AOL81) & MH553607 (AOL24) & 1 \\
\hline Lophiosilurus alexandri & $\mathrm{B}$ & São Franciscor ${ }^{\mathrm{r}}$ & -- & HM405152 & 6 \\
\hline Lophiosilurus alexandri & $\mathrm{B}$ & São Franciscor ${ }^{r}$ & JX899754 & --- & 2 \\
\hline Microglanis sp. & $\mathrm{C}$ & Acacias $^{r}$ & MH553599 (AOL95) & MH553604 (AOL95) & 1 \\
\hline Rhyacoglanis anulatus & $\mathrm{C}$ & Negro $^{r}$ & (AOL97-98) & MH553605-06 (AOL97-98) & 1 \\
\hline Rhyacoglanis pulcher & -- & -- & - & EU179812 & 3 \\
\hline Pimelodus yuma & $\mathrm{C}$ & HZ1-Magdalena ${ }^{r}$ & MH595780 & MH553610 & 1 \\
\hline Pseudoplatystoma magdaleniatum & $\mathrm{C}$ & HZ1-Magdalena ${ }^{\mathrm{r}}$ & MH595781 & MH553611 & 1 \\
\hline
\end{tabular}
2 


\section{Figure 1}

Sampling localities of Pseudopimelodus species in different trans- and cis-Andean rivers in Colombia.

Hydrographical sub-zones are denoted by colored circles : Magdalena River-upper sector (dark blue), Magdalena River middle and lower sectors, Cauca River- lower sectors and San Jorge River (purple), Cauca River-upper and middle sectors (light blue), Caribbean drainage Atrato River and Sinú River (red), Amazon River basin (yellow), Orinoco River basin (orange). Location of Antioquian Plateau in the northern Central Cordillera (solid square), Garzón Massif at the southern tip of the Eastern Cordillera (doted rectangle) and Vaupés Arch (white dashed line) are shown. Map Image Layer by NOAA National Centers for Environmental Information (NCEI). 


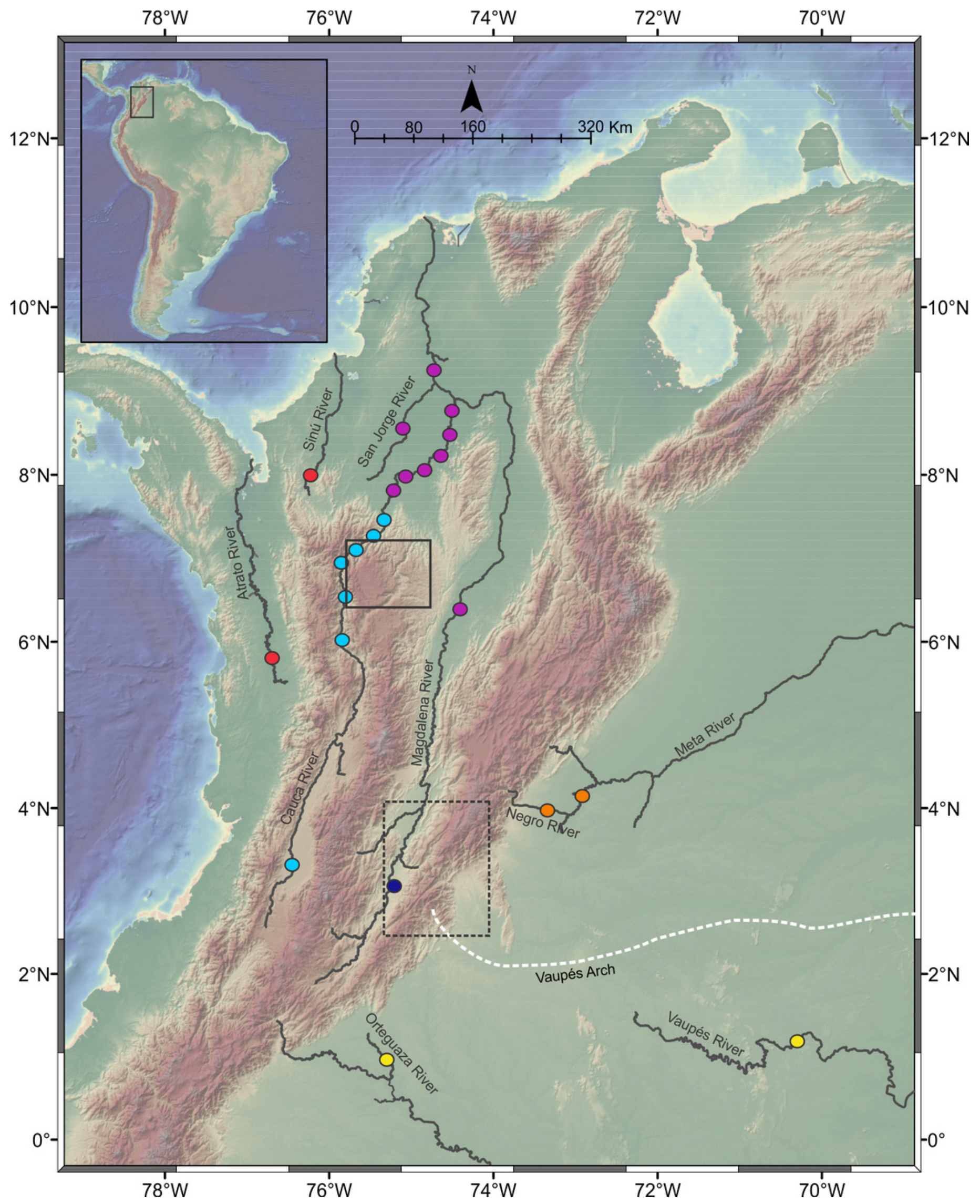


Figure 2

Single Locus Species Discovery Analysis showing the Maximum clade credibility tree from Beast.

Bayesian posterior probabilities above 0.95 are shown as dark nodes. Point estimate species delimitations are shown by method as colored boxes. Tree was presented using the ggtree_1.6.11 package (Yu et al., 2016). 

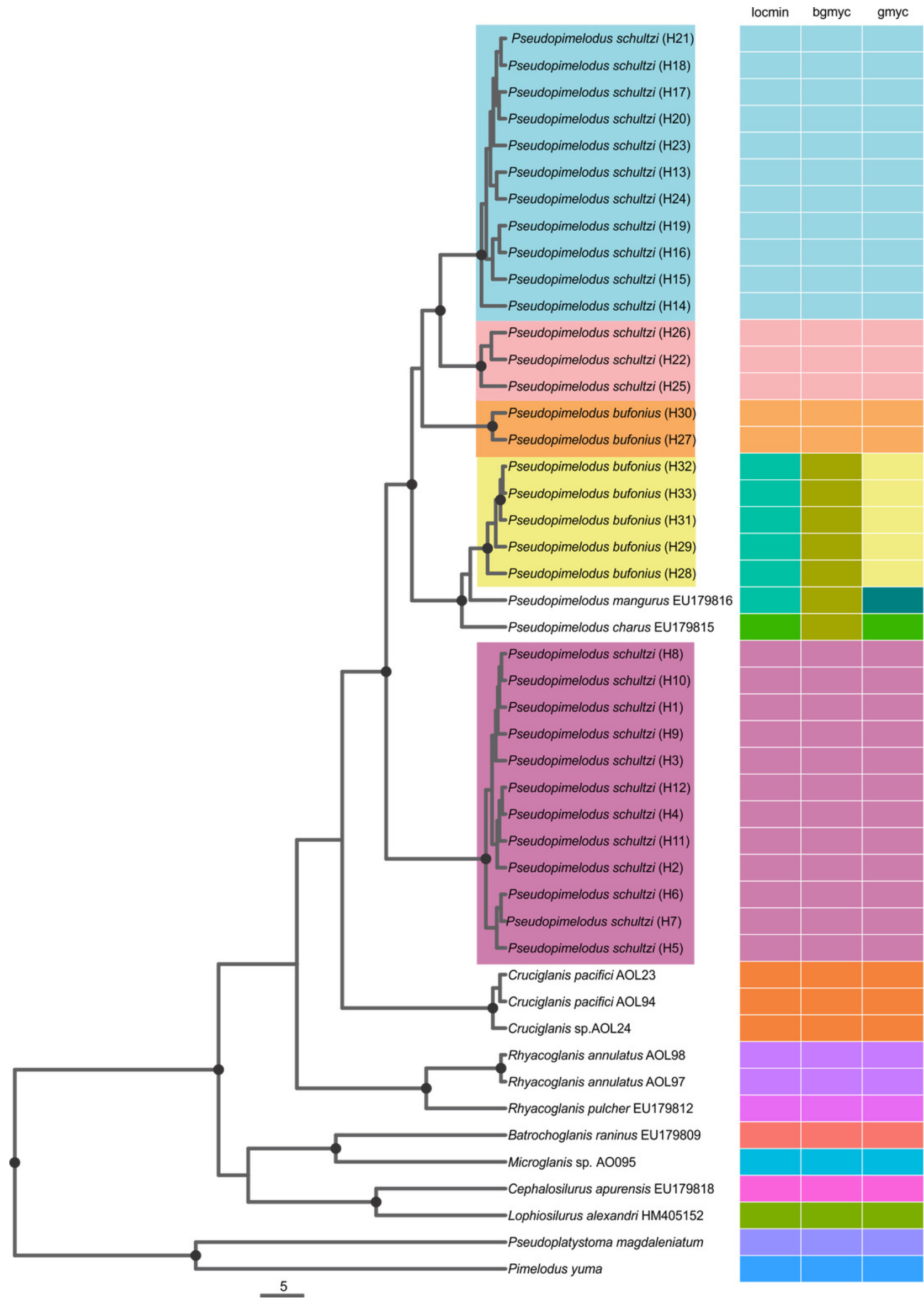


\section{Figure 3}

Median-joining network of Pseudopimelodus cox1 haplotypes.

Hydrographical sub-zones are denoted by the colors of circles: Magdalena River and Cauca River- lower sectors and San Jorge River (purple), Cauca River-upper and middle sectors (blue), Magdalena river middle sector (pink), Magdalena River-upper sector (green),

Caribbean drainage - Atrato River and Sinú River (red), Orinoco River basin (orange) and Amazon River basin (yellow). 


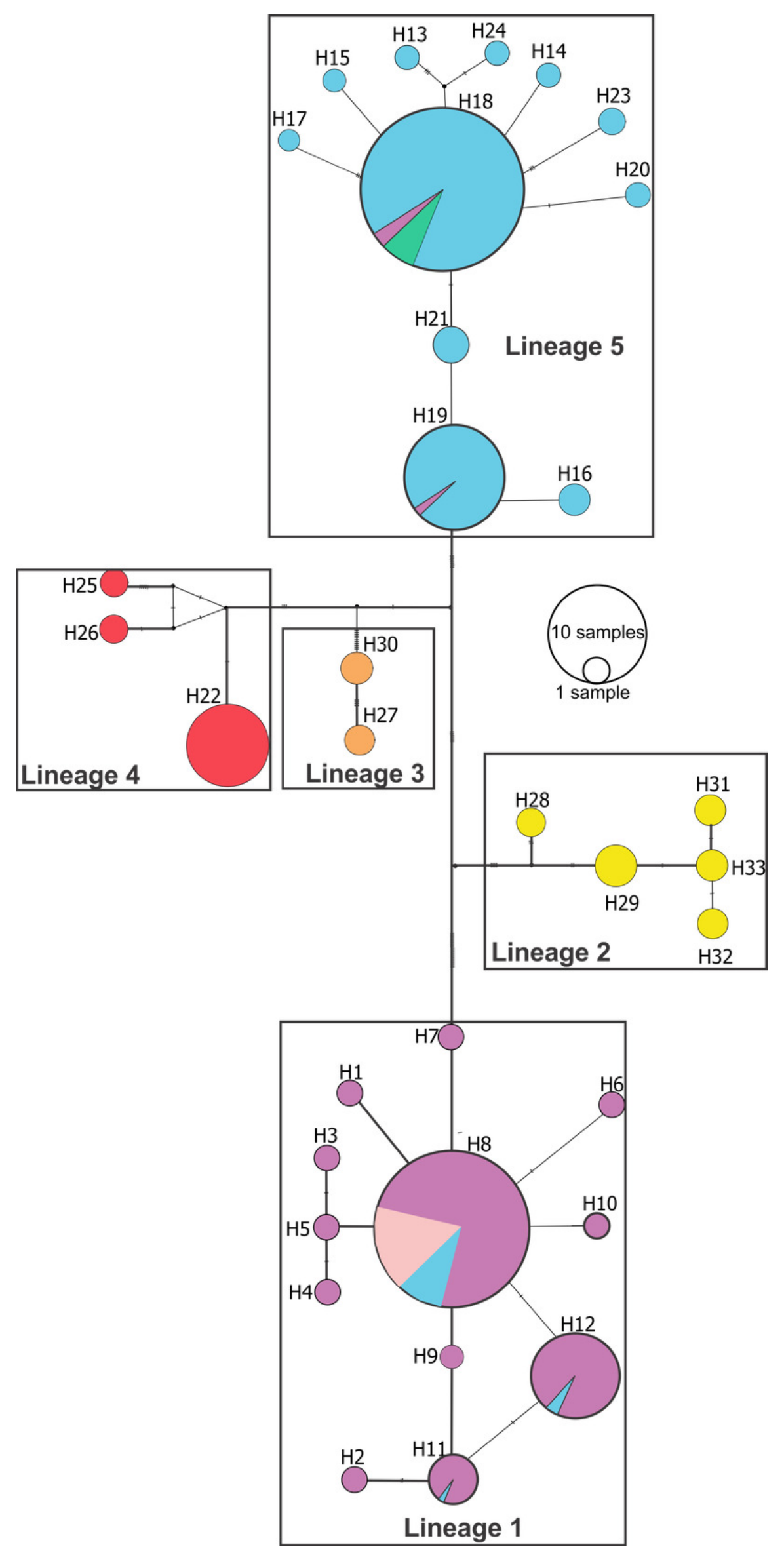

Peer) reviewing PDF | (2018:07:29424:2:1:NEW 21 Mar 2020) 


\section{Figure 4}

Dated species tree of the family Pseudopimelodidae generated using StarBEAST2.

Vertical dashed blue, black and grey lines indicates uplift of the Antioqueño Plateau, Vaupés Arch and Eastern Cordillera, respectively. Calibrated nodes are denoted by a black circle; time in mya is indicated by the scale bar. 


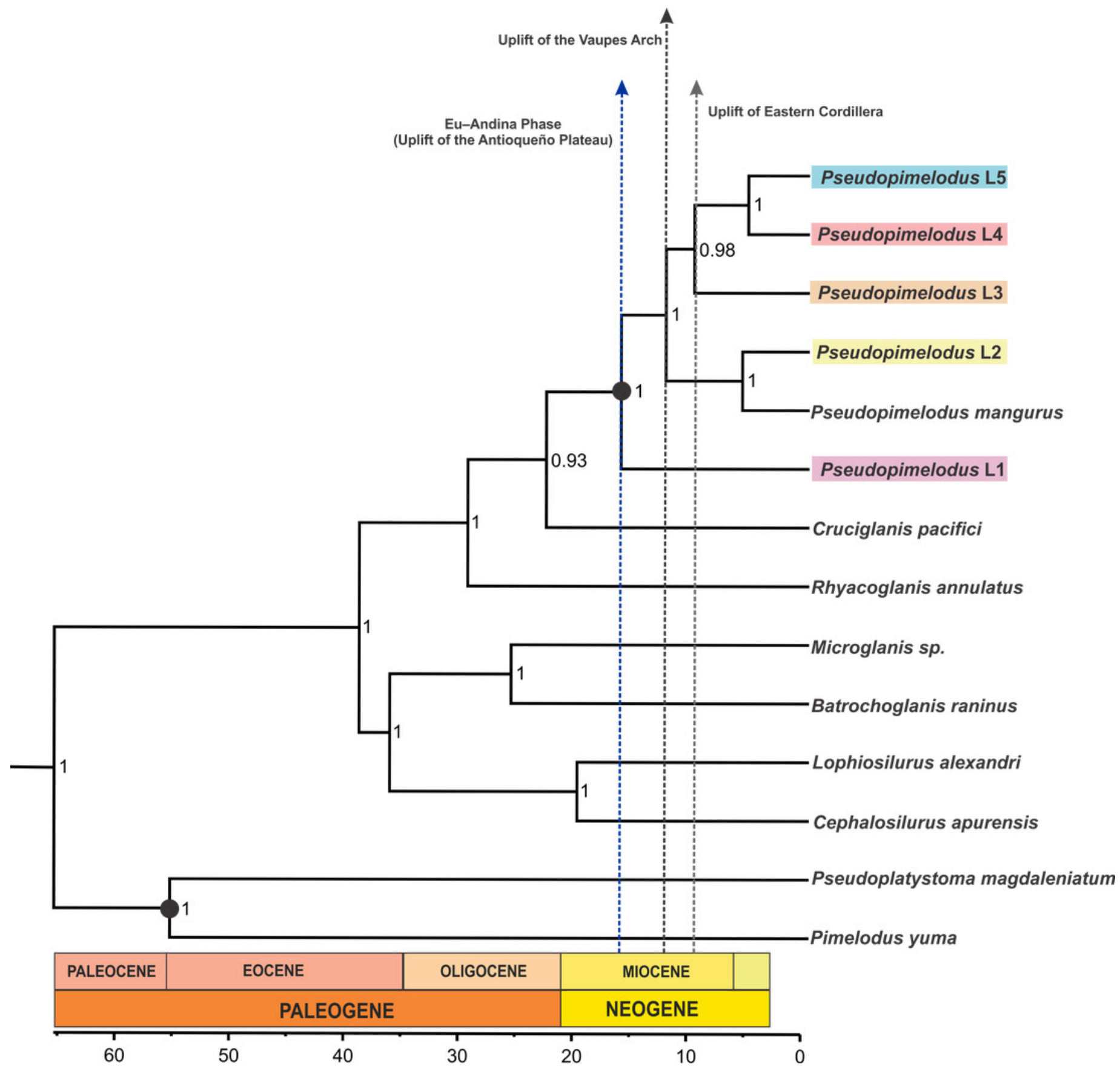

